\title{
FINTECH REGULATORY SANDBOXES IN AUSTRALIA AND MALAYSIA: A LEGAL ANALYSIS
}

\author{
Maryam Khalid* \\ Sherin Kunhibava**
}

\begin{abstract}
With the era of digitalization, regulatory sandboxes have been the trend adopted by most financial regulators around the world in regulating financial technology (fintech). Regulatory sandboxes act as a pilot programme to regulate fintech services and products with several legal exemptions given to the service providers within established parameters. In 2016, the Australian Securities and Investments Commission and the Malaysian Central Bank followed the United Kingdom's Financial Conduct Authority (FCA) to introduce regulatory sandboxes within their legal framework. To date, previous literature has only provided a minimal analytical overview of the Malaysian and Australian regulatory sandbox. Hence, this article aims to fill that gap in literature. The methodology used for this study is both doctrinal and comparative legal analysis. The main objective of this study is to analyse the key characteristics of fintech regulatory sandboxes by comparing the Australian and Malaysian regulatory structures of these sandboxes. Due to nascent nature of Malaysian and Australian fintech regulations, this contributes to the growing knowledge in the financial regulation literature. Moreover, the findings on the operation of the regulatory sandboxes in both jurisdictions is expected to bring practical value for further research.
\end{abstract}

Keywords: innovation, digitalization, financial regulation, fintech, regulatory sandbox.

* Ph.D. student, Faculty of Law, University Malaya. Email: maryamkmn@um.edu.my.

** Senior Lecturer, Faculty of Law, University Malaya. Email: sherin@um.edu.my.

[Received: 16 July 2019, Accepted: 2 January 2020, Published: 30 June 2020] 


\title{
PENGAWALSELIAAN TEKNOLOGI KEWANGAN SANDBOX: SATU ANALISIS PERUNDANGAN
}

\begin{abstract}
ABSTRAK
Di era digitalisasi kini, pengawalseliaan sandbox telah menjadi satu trend yang diterima pakai oleh kebanyakan pengawal selia kewangan di serata dunia dalam mengawal selia teknologi kewangan (fintech). Pengawalseliaan sandbox bertindak sebagai program perintis dalam mengawal selia perkhidmatan dan produk-produk fintech dengan beberapa pengecualian undang-undang diberikan kepada pembekal perkhidmatan di dalam perimeter yang ditetapkan. Pada tahun 2016, Suruhanjaya Sekuriti dan Pelaburan Australia serta Bank Negara Malaysia mengikuti jejak Pihak Berkuasa Kelakuan Kewangan United Kingdom (FCA) dalam memperkenalkan pengawalseliaan sandbox dalam rangka kerja perundangan mereka. Sehingga kini, kajian-kajian terdahulu hanya menyediakan analisis gambaran keseluruhan yang minimum mengenai pengawalseliaan sandbox di Australia dan Malaysia. Oleh itu, makalah ini bertujuan untuk mengisi jurang tersebut. Kaedah yang digunakan di dalam kajian ini adalah melalui kaedah doktrin dan analisa perbandingan undang-undang. Objektif utama kajian ini adalah untuk menganalisa ciri-ciri penting pengawalseliaan sandbox dengan melihat struktur dari Australia dan Malaysia. Oleh kerana peraturan fintech di Malaysia and Australia masih baru, maka ini akan menyumbang kepada pengetahuan am dalam literatur peraturan kewangan. Tambahan, dapatan mengenai operasi pengawalseliaan sandbox di kedua-dua bidang kuasa akan memberi nilai praktikal untuk kajian lanjut.
\end{abstract}

Kata kunci: rekaan baru, digitalisasi, peraturan kewangan, fintech, pengawalseliaan sandbox.

\section{INTRODUCTION}

As a result of digitalization of finance and technology, fintech has been identified as the preferred solution for financial consumers. The latest survey conducted by Ernst \& Young in 2019 showed that there was a sharp increase in the percentage of financial consumers that opted for fintech solutions, especially in the money transfer and 
payments services sector. ${ }^{1}$ Fintech, has had a long history with its inception in the financial market and commercial usage of the telegraph in the $19^{\text {th }}$ century, followed by the introduction of automated teller machines in the 1960s. ${ }^{2}$ Although fintech has started some time ago, it is only post 2008 Global Financial Crisis ('GFC') that it became known as fintech, i.e., financial innovations that leverage on technology to deliver fast, efficient and convenient financial services to the customers in the financial markets. ${ }^{3}$

With the rapid changes via technology, financial regulators are placed with new regulatory burdens. Previously, they only needed to focus on financial stability and consumer protection. ${ }^{4}$ With the emergence of fintech in the financial system, the regulators are expected to ensure financial stability and to protect financial consumers, with a caution not to hamper innovation. In balancing between the three regulatory burdens, one of the toolkits adopted by financial regulators in regulating fintech is through regulatory sandboxes. A regulatory sandbox may be referred to as a pilot project for fintech companies to test fintech products within established parameters together with several legal exemptions to avoid materialization of any systemic risks that are attached to the fintech products. The idea of the financial regulatory sandbox originated from the software development industry as a safe space to run applications in an isolated environment in order to avoid affecting other running programmes. ${ }^{5}$

1 Ernst \& Young, Global Fintech Adoption Index, 2019).

2 Douglas W. Arner, Janos Barberis and Ross P. Buckley, 'Fintech, regtech and reconceptualization of financial regulation' (2017) 37 Northwestern Journal of International Law \& Business 371.

3 Douglas W. Arner, Janos Barberis and Ross P. Buckley, 'The evolution of fintech: a new post-crisis paradigm' (2016) Journal International Law 1271.

4 Financial Stability Board, Financial Stability Implications from FinTech: Supervisory and Regulatory Issues that Merit Authorities' Attention, 2017) The Financial Stability Board's stock take showed that majority of regulators are adding promotion of innovation as one of their policy objectives in regulating fintech.

5 Michael Masss, 'A Theory and Tools for Applying Sandboxes Effectively' (Ph.D., Carnegie Mellon University 2016). 
Based on Google search trends, interest in the term 'regulatory sandbox' started in 2015. ${ }^{6}$ Perhaps, this was contributed by the United Kingdom's financial regulator - Financial Conduct Authority (FCA)'s Project Innovate, which was announced in October 2014 to encourage innovative solutions for financial consumers. ${ }^{7}$ Project Innovate included a preliminary introduction of regulatory sandbox as one of FCA's methods in regulating fintech. The FCA only kicked off its regulatory sandbox in October $2016 .{ }^{8}$ Nevertheless, a similar concept can be identified from a programme which was initiated in 2012 by the United States' (US) Consumer Financial Protection Bureau (CFPB) under its Project Catalyst. ${ }^{9}$

\section{REGULATORY STRUCTURE OF SANDBOXES IN MALAYSIA AND AUSTRALIA}

In 2016, the Australian Securities and Investments Commission (ASIC) and the Malaysian Central Bank (BNM) introduced

6 Google, 'Regulatory Sandbox: Interest Over Time' <https://trends.google.com/trends/explore?date=today\%205y\&q=regulatory\%20sandbox $>$ accessed 1 July 2019.

7 UK Financial Conduct Authority, 'Project Innovate' 2014) <http://www.meti.go.jp/committee/kenkyukai/sansei/fintech/pdf/006_02 _00.pdf $>$ accessed 3 September 2018.

8 UK Financial Conduct Authority, 'Regulatory Sandbox' 2015) <https://www.fca.org.uk/firms/regulatory-sandbox > accessed 3 September 2018.

9 Consumer Financial Protection Bureau, 'Consumer Financial Protection Bureau Launches Project Catalyst to Spur Consumer-Friendly Innovation' 2012) <https://www.consumerfinance.gov/aboutus/newsroom/consumer-financial-protection-bureau-launches-projectcatalyst-to-spur-consumer-friendly-innovation/> accessed 1 July. CFPB launched Project Catalyst to promote a consumer-friendly innovation environment between the fintech players, the regulators (both in federal and at state level) and financial consumers. CFPB allowed fintech players to test their products with the customers with a condition that there must be transparency of the financial products throughout the course of usage of the product. Furthermore, legal exemption termed as 'No Action Letter' will be provided to the fintech players so long as they place the required safety measures, in order to mitigate possible harm that customers may face. 
regulatory sandboxes within their legal framework. Currently, more than 50 jurisdictions have adopted regulatory sandboxes in their financial regulation. ${ }^{10}$ The regulatory burden of regulators has increased since the focus of the financial consumer is now on the digital market. In order to cater for this additional burden and ensure that regulation will not hamper innovation, regulatory sandbox has been introduced as one of the tools to regulate fintech. However, there is little information as to its structure, legal concept and application. To date, previous literature has only provided a number of analytical overviews on the UK's regulatory sandbox. ${ }^{11}$ However, only minimal analytical research has been published on Australian ${ }^{12}$ and Malaysian regulatory sandboxes. Thus, the main objective of this article is to address the key characteristics of a regulatory sandbox by analysing the different approaches adopted by the Malaysian and Australian jurisdictions in developing regulatory sandbox as part of their fintech regulation.

There are three justifications for selecting the jurisdictions for this article. Firstly, Malaysia and Australia use English as the primary language in the regulation ${ }^{13}$ subject matter and all relevant documents can be retrieved in English. Secondly, both jurisdictions share the common law background and heritage. ${ }^{14}$ Thirdly, to serve the need of Malaysia researchers, the choice in comparing its sandbox to the

10 Ross P Buckley and others, 'Building Fintech Ecosystems: Regulatory Sandboxes, Innovation Hubs And Beyond' (2019) 72 University of New South Wales Law Research Series.

11 See Iris H-Y Chiu, 'A Rational Regulatory Strategy for Governing Financial Innovation' (2017) 8 European Journal of Risk Regulation 743Dirk A. Zetzsche and others, 'From regulatory sandboxes to smart regulation' (2017) 23 Fordham Journal Of Corporate \& Financial Law 31 Kieran Garvey and others, Guide To Promoting Financial \& Regulatory Innovation, 2018).

12 See Lev Bromberg, Andrew Godwin and Ian Ramsay, 'Fintech Sandboxes: Achieving Balance Between Regulation And Innovation' (2017) 28 Journal of Banking and Finance Law and Practice 314.

13 Mark Van Hoecke, 'Methodology of Comparative Legal Research' (2015) Law and Method 1.

14 Max Rheinstein, 'Comparative Law, Its Functions, Methods And Usages' (1968) 22 Arkansas Law Review \& Bar Association Journal 415; All different laws from different countries in the world can be classified as derived from the same genus. 
Australian is due to the uniqueness of the Australian sandbox which runs on an industry licensing exemption framework. ${ }^{15}$

This article adopts doctrinal and comparative legal methodology. A doctrinal legal approach is used to locate and identify the laws which are applicable to the regulatory sandbox in Australia and Malaysia. Meanwhile, comparing the laws of the two jurisdictions will lay out in detail the common thresholds of sandbox as a tool for financial regulation. It is important to note that most of the statutory documents and reports are obtained from the official websites of the two regulators i.e., ASIC and BNM for Australia and Malaysia respectively. By reviewing the documents using comparative legal methodology, this article provides a description of regulatory sandbox in order to develop an understanding of their structure within the selected jurisdiction. ${ }^{16}$

This article focuses on three main points. Firstly, the powers and mandates of the regulator in Australia and Malaysia with respect to regulatory sandbox. Secondly, the discussion will cover the criteria for fintech platforms who seek to participate in the sandbox. Thirdly, a comparative analysis of the key characteristics of the regulatory sandbox between the two jurisdictions. By examining each of the sandboxes and understanding them within the context of the selected jurisdictions' market, regulatory regimes and their operating models, the understanding of the structure of a sandbox will be enhanced. Finally, this article concludes with the general key characteristics of a sandbox structure in regulating fintech.

The change in today's world due to technology is unavoidable, especially in the financial sector. With rapid changes in technology, financial system regulators are placed with new burdens. Previously, financial regulators needed to focus on the financial stability and consumer protection. With the evolution of fintech in the financial system, regulators are now also expected to encourage innovation.

15 Bromberg, Godwin, and Ramsay, "Fintech Sandboxes: Achieving Balance Between Regulation And Innovation."

${ }^{16}$ Comparative legal methodology can be used to advance knowledge on a particular legal issue. See Marie-Luce Paris, The Comparative Method in Legal Research: The Art of Justifying Choices (Legal Research Methods: Principles and Practicalities, Clarus Press 2016). 
Hence, regulatory sandbox might help ease the burden and act as a toolkit to meet the regulator's new obligation. The regulator's balancing act of their regulatory burden is illustrated in the Figure 1 below.

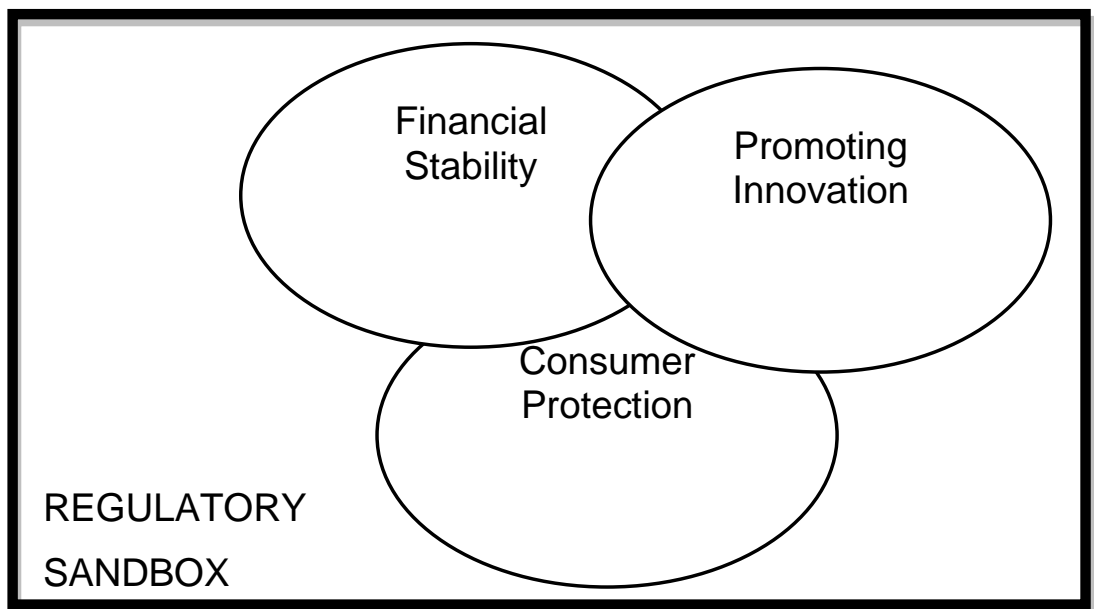

Figure 1: Regulatory sandbox serves to balance the regulator's regulatory burden. ${ }^{17}$

\section{ROLE OF AUSTRALIAN AND MALAYSIAN FINANCIAL REGULATORS IN FINTECH SANDBOXES}

This section investigates the role and powers of financial regulators in implementing fintech sandboxes. Consequently, it will also draw contrasting objectives of each sandbox in order to identify whether the mandates are consistent with the financial regulation laws. In the later part of this section, this article will discuss the processes of both regulatory sandboxes. The discussion begins with Australia.

\section{Financial Service Regulation and Fintech Sandbox in Australia}

The Australian financial sector stands firmly on its twin peaks system regulated by ASIC and the Australian Prudential Regulation Authority (APRA). The strength in the financial sector lies on the

\footnotetext{
${ }^{17}$ Source: Author.
} 
dynamics and the division of regulatory architecture where ASIC regulates matters in relation to corporate markets, financial services consumer protection and market integrity, while APRA is focused on prudential regulations. ${ }^{18}$. ASIC's responsibility also covers regulating the developers, sellers and advisors in terms of credit products and investments. ${ }^{19}$ Thus, ASIC as the Commonwealth Government Body is the regulator overseeing matters in relation to the regulatory sandbox. The central bank, Reserve Bank of Australia (RBA), "remains responsible for monetary policy and financial stability, including ensuring a safe and reliable payments system". ${ }^{20}$

ASIC's establishment was based on the recommendation of Wallis Inquiry which depended on the need for a market conduct regulator for Australia. ${ }^{21}$ ASIC's regulatory objectives are expressly mandated in the Australian Corporations Act 2001 which mandates ASIC to strive, maintain, facilitate and promote the performance of the financial system and entities within that system in the interest of commercial certainty. ${ }^{22}$

It was highlighted by the Australian government that in 2015, the services sector took up to 1.6 trillion Australian dollars in the economy, whereby the financial services export made up around five per cent of Australia's services export. ${ }^{23}$ In 2015, the Australian fintech market size was a staggering AUD \$1.3 billion, and approximately 10,000 people were working in the fintech industry. ${ }^{24}$ To date, around 600 fintech companies are registered in the leading

18 Andrew Godwin and Ian Ramsay, 'The Legal and Regulatory Anatomy of Australia's System of Financial Regulation' (CIFR, 2015) <https://papers.ssrn.com/sol3/papers.cfm?abstract_id=2657355> accessed 17 April 2019.

19 ASIC, "Fintech: ASIC's Approach and Regulatory Issues" (Melbourne Money \& Finance Conference, Melbourne, ASIC, July 2016 2016) 6.

20 Godwin and Ramsay, 'The Legal and Regulatory Anatomy of Australia's System of Financial Regulation' 2.

${ }^{21}$ Commonwealth of Australia, Financial System Inquiry Final Report, 1997) http://www.treasury.gov.au/fsi.

22 Corporations Act 2001 (Cth) s 1 (2) (a) - (g).

23 Innovation and Science Department of Industry, Australian Industry Report, 2015) 7.

24 ASIC, "Fintech: ASIC's Approach and Regulatory Issues". 3. 
Australian fintech directory website. ${ }^{25}$ By 2020, it is predicted that the fintech industry will reach up to AUD 4.2 billion. ${ }^{26}$ Thus, seeing the potential positive outcomes for the economy, the Australian government urged for further development opportunities in financial services export by bringing in innovative ideas into the market. ${ }^{27}$ Based on the growing fintech market size and the hurdles faced by start-ups, ASIC decided to open its own Innovation Hub on 11 April $2015 .^{28}$ ASIC was of the view that 'it is important to assist start-ups because often they lack the resources to think about how the regulatory framework may apply to them, where they have these great ideas about providing better outcomes for consumers and for markets' ${ }^{29}$

Generally, providers of financial and credit services in Australia are required to be licensed in order to carry out their businesses. ${ }^{30}$ This is in line with the new regulatory function placed on ASIC to match the demands of fintech products. Therefore, ASIC issued a consultation paper in June 2016 seeking information from all stakeholders on how to move forward and inquiring on the best tools in regulating fintech within the Australian financial environment. ${ }^{31}$ Under the consultation paper, ASIC further explained the existing flexibility that it offers especially to innovative start-ups. Furthermore, in 2016, ASIC made several amendments to the

25 Australian Fintech, 'Membership' (Australian Fintech, 2019) <https://australianfintech.com.au/memberships/> accessed 21 June 2019.

26 Australian Fintech, 'Fintech Market Growth to Add A\$1 Billion New Value to Australian Economy by 2020' (Australian Fintech, 2019) $<$ https://australianfintech.com.au/fintech-market-growth-to-add-a1-

billion-new-value-to-australian-economy-by-2020/> accessed 21 June 2019 this write-up was based on a report publish by Frost \& Sullivan titled 'Fintech in Australia - Trends, Forecasts and Analysis 2015'.

27 Ibid 2.

28 ASIC, "Fintech: ASIC's Approach and Regulatory Issues".

29 Toronto Centre, To Protect or to Foster Innovation: An Inside Look at a Regulator's Initiative to do Both (Toronto Centre 2019) ASIC was represented by Mark Adams, their Senior Executive Leader of Strategic Intelligence in this podcast.

30 s 911A Corporations Act (Cth) 2001.

${ }^{31}$ Australian Securities \& Investments Comission, Consultation Paper 260: Further measures to facilitate innovation in financial services (ASIC 2016). 
previous Regulatory Guide 105 issued in 2007 to make room for small scale but heavily automated players to nominate professional third parties as responsible managers ${ }^{32}$ to accommodate fintech startups.

The consultation paper presented proposals which required comments from stakeholders on setting up the Australian sandbox. Finally, ASIC issued the Regulatory Guide 257 in December 2016, allowing the fintech players to test their products without holding the required license. ${ }^{33}$

From the outlook of fintech licensing exemption framework and the Australian regulatory sandbox as a whole, there are several restrictions of the Australian sandbox highlighted by stakeholders that can be summed up. Firstly, the licensing exemption framework prescribes limitation in terms of the scope of the financial services and credit activities and the products offered in order to obtain an exemption. This is one of the reasons why there is a lack of participation from the fintech players to notify ASIC in obtaining the licensing exemption. ${ }^{34}$ Hence, one can conclude that act of participant in not notifying ASIC, is intentional to promote innovation in financial services. This was actually not achieved under the regulatory sandbox.

Secondly, the structure of the Australian regulatory sandbox might trade-off consumer protection. Although ASIC's approach

32 Australian Securities \& Investments Commission, Regulatory Guide 105: Licensing Organisational Competence (ASIC 2016) 105.26105.33 .

${ }^{33}$ Australian Securities \& Investments Commission, Regulatory Guide 257: Testing fintech products and services without holding an AFS or credit licence (ASIC 2017).

${ }^{34}$ Australian Securities and Investment Commission, 'Regulatory sandbox: Licence Exemption Users' (ASIC, 2019) <https://asic.gov.au/forbusiness/innovation-hub/fintech-regulatory-sandbox/regulatorysandbox-licence-exemption-users/> accessed 21 June 2019. Although the fintech market is growing rapidly in Australia however to date, there is only one active fintech player in this framework. Since 2017, there were only six fintech players that gave written notice to ASIC on their intention to carry out fintech businesses and accepted to the fintech licensing framework. 
should be praised as it embraces flexibility and principle-based financial regulation, ${ }^{35}$ consumer protection is vulnerable as exemption is given after notification by fintech players to ASIC. A number of submissions by the stakeholders, especially the consumer protection groups, have raised their concern on the adverse effects that consumers might grapple with due to the flexibility that ASIC offer to fintech players in getting licensing exemption. ${ }^{36}$

Realizing these restrictions, the Australian government in its 2017/2018 Federal Budget announced the proposed an Enhanced Regulatory Sandbox that will be legislated after a thorough consultation with all stakeholders. ${ }^{37}$ The Treasury intends to extend the current regulatory sandbox framework in a number of areas. One of the main reasons for having the enhanced regulatory sandbox is to enable fintech players to test their services and products without the need to go through the licensing regime. ${ }^{38}$ From the submissions by

35 Principles-based regulation is the basis that a regulatory sandbox rests its conception, where the regulation is flexible and communicative relationship exists between the regulator and regulated entities as compared to rules based regulation. See Dan Awrey, 'Regulating Financial Innovation: A More Principles-Based Alternative' (2011) 5 Brooklyn Journal of Corporate, Financial and Commercial Law 273. Julia Black, 'Forms and Paradoxes of Principles Based Regulation' <http://www.lse.ac.uk/law/working-paper-series/2007-08/WPS2008-13Black.pdf $>$ Julia Black, 'The Rise, Fall and Fate of Principles Based Regulation' <http://eprints.lse.ac.uk/32892/1/WPS201017_Black.pdf $>$ Julia Black, Martyn Hoper and Christa Band, 'Making a Success of a Principles-Based Regulation' (2007) 1 Law \& Financial Market Review 191.

36 ASIC, Report 508: Response to Submissions on Consultation Paper 260, Further Measures to Facilitate Innovation in Financial Services, 2016) 12 .

37 Government of Australia, Fact Sheet Budget 2017: Backing Innovation and Fintech, (Australia 2017).

38 Government of Australia, Exposure Draft Explanatory Statement Corporations Act 2001, National Consumer Credit Protection Act 2009 Corporations (FinTech Sandbox Australian Financial Services Licence Exemption) Regulations 2017 and National Consumer Credit Protection (FinTech Sandbox Australian Credit Licence Exemption) Regulations 2017 (2017) 1. 
the stakeholders, the overall comments viewed the current regulatory sandbox as limited and circumscribed. ${ }^{39}$

Table 1 identifies specific differences between ASIC's regulatory sandbox (on fintech licensing exemption framework) and the proposed changes by the Treasury based of Enhanced Regulator Sandbox.

\begin{tabular}{|c|c|c|}
\hline $\begin{array}{l}\text { Proposed } \\
\text { Areas of } \\
\text { Extension }\end{array}$ & $\begin{array}{l}\text { ASIC's Regulatory } \\
\text { Sandbox }\end{array}$ & $\begin{array}{l}\text { Enhanced Regulatory } \\
\text { Sandbox }\end{array}$ \\
\hline $\begin{array}{l}\text { Accessing the } \\
\text { sandbox }\end{array}$ & $\begin{array}{l}\text { More focused on assisting } \\
\text { innovative players to tap } \\
\text { the market and to reduce } \\
\text { the regulatory barriers and } \\
\text { costs that may hinder them } \\
\text { from doing so. }{ }^{40}\end{array}$ & $\begin{array}{l}\text { The proposed enhanced } \\
\text { regulatory sandbox will } \\
\text { allow innovative players } \\
\text { that may include big } \\
\text { institutions to access the } \\
\text { sandbox several times to } \\
\text { test the broad eligible } \\
\text { products to be offered as } \\
\text { long as the players are } \\
\text { not licensed, and the } \\
\text { products have not been } \\
\text { tested before. }{ }^{41}\end{array}$ \\
\hline $\begin{array}{l}\text { Eligible } \\
\text { financial } \\
\text { services and } \\
\text { credit } \\
\text { activities }\end{array}$ & $\begin{array}{l}\text { 1. For financial services, it } \\
\text { is only limited to: } \\
\text { i. providing general } \\
\text { advice and personal } \\
\text { advice; } \\
\text { ii. dealing with financial } \\
\text { products. }\end{array}$ & $\begin{array}{l}\text { 1. The legislative drafts } \\
\text { have included for } \\
\text { financial services as } \\
\text { follows: } \\
\text { i. applying or acquiring } \\
\text { any eligible financial } \\
\text { products; } \\
\text { ii. issuing, varying or }\end{array}$ \\
\hline
\end{tabular}

39 ASIC, Report 508: Response to Submissions on Consultation Paper 260, Further Measures to Facilitate Innovation in Financial Services.

${ }^{40}$ Commission, Regulatory Guide 257: Testing fintech products and services without holding an AFS or credit licence. RG 257.13.

${ }^{41}$ Australia, Exposure Draft Explanatory Statement Corporations Act 2001, National Consumer Credit Protection Act 2009 Corporations (FinTech Sandbox Australian Financial Services Licence Exemption) Regulations 2017 and National Consumer Credit Protection (FinTech Sandbox Australian Credit Licence Exemption) Regulations 20171. 


\begin{tabular}{|c|c|c|}
\hline & $\begin{array}{l}\text { 2. For credit activities, the } \\
\text { scope is only limited to } \\
\text { credit service which refers } \\
\text { to credit assistance or } \\
\text { acting as middle person in } \\
\text { credit services. }{ }^{4}\end{array}$ & $\begin{array}{l}\text { disposing any } \\
\text { eligible financial } \\
\text { products; } \\
\text { iii. } \begin{array}{l}\text { issuing, varying and } \\
\text { disposing non-cash } \\
\text { facility; and }\end{array} \\
\text { iv. providing crowd- } \\
\text { fund service. } \\
\text { 2. Meanwhile, for credit } \\
\text { activities, the scope has } \\
\text { widened to include all } \\
\text { credit contracts and } \\
\text { services; } \\
\text { i. with a term that does } \\
\text { not exceed } 4 \text { years; } \\
\text { and } \\
\text { ii. a credit limit of more } \\
\text { than } \$ 2,000 \text { and less } \\
\text { than } \$ 25,000.43\end{array}$ \\
\hline $\begin{array}{l}\text { Types of } \\
\text { eligible } \\
\text { financial } \\
\text { products and } \\
\text { credit } \\
\text { activities that } \\
\text { are available } \\
\text { to retail } \\
\text { clients and }\end{array}$ & $\begin{array}{l}\text { 1. Expressly exclude life } \\
\text { insurance, superannuation } \\
\text { and international securities } \\
\text { for retail clients. }{ }^{44} \\
\text { 2. The scope for types of } \\
\text { products and credit } \\
\text { activities were limited and }\end{array}$ & $\begin{array}{l}\text { 1. Life insurance, } \\
\text { international securities } \\
\text { and superannuation } \\
\text { products are included } \\
\text { although subject to } \\
\text { exposure limit. }{ }^{46} \\
\text { 2. For wholesale clients, }\end{array}$ \\
\hline
\end{tabular}

42 Commission, Regulatory Guide 257: Testing fintech products and services without holding an AFS or credit licence. RG 257.61-64.

43 Australia, Exposure Draft Explanatory Statement Corporations Act 2001, National Consumer Credit Protection Act 2009 Corporations (FinTech Sandbox Australian Financial Services Licence Exemption) Regulations 2017 and National Consumer Credit Protection (FinTech Sandbox Australian Credit Licence Exemption) Regulations 2017, 6 and 13.

44 Commission, Regulatory Guide 257: Testing fintech products and services without holding an AFS or credit licence. RG 257.68. 


\begin{tabular}{|l|l|l|}
\hline $\begin{array}{l}\text { wholesale } \\
\text { clients. }\end{array}$ & $\begin{array}{l}\text { many were expressly } \\
\text { excluded. }\end{array}$ & $\begin{array}{l}\text { the services that can be } \\
\text { tested have opened up to } \\
\text { all types of products } \\
\text { except derivatives and } \\
\text { credit margin lending } \\
\text { facilities. }\end{array}$ \\
\hline $\begin{array}{l}\text { Requirements } \\
\text { in using } \\
\text { Regulatory } \\
\text { Sandbox }\end{array}$ & $\begin{array}{l}\text { When applying, the players } \\
\text { are required to write a short } \\
\text { description of their } \\
\text { business and the innovation } \\
\text { that they are bringing into } \\
\text { the market. }\end{array}$ & $\begin{array}{l}\text { There is no specific } \\
\text { requirement for } \\
\text { innovative use of } \\
\text { technology. }\end{array}$ \\
\hline Duration & $\begin{array}{l}\text { 12 months with application } \\
\text { for extension afterwards. }\end{array}$ & $\begin{array}{l}\text { 24 months without } \\
\text { further extension. }\end{array}$ \\
\hline
\end{tabular}

Table 1: Differences between ASIC's Regulatory Sandbox and Enhanced Regulatory Sandbox. ${ }^{50}$

It is important to note that the enhancement proposals however did not include any changes with regards to consumer protection.

Subsequent to the issuance of draft legislations on Enhanced Regulatory Sandbox (ERS), ASIC issued its Consultation Paper

46 Australia, Exposure Draft Explanatory Statement Corporations Act 2001, National Consumer Credit Protection Act 2009 Corporations (FinTech Sandbox Australian Financial Services Licence Exemption) Regulations 2017 and National Consumer Credit Protection (FinTech Sandbox Australian Credit Licence Exemption) Regulations 2017 , 8.

45 Ibid RG 257.58.

47 Ibid RG 257.113.

48 Ibid RG 257.71.

49 Australia, Exposure Draft Explanatory Statement Corporations Act 2001, National Consumer Credit Protection Act 2009 Corporations (FinTech Sandbox Australian Financial Services Licence Exemption) Regulations 2017 and National Consumer Credit Protection (FinTech Sandbox Australian Credit Licence Exemption) Regulations 2017 , 6 and 13.

50 Compiled by Author. 
$297,{ }^{51}$ stating that should the Australian Government implement the ERS, reviews will be made to the current regulations which implies a revocation of the current regulatory sandbox regime. ${ }^{52}$, Subsequently, on the 10th February 2020 the Australian Parliament passed the Treasury Laws Amendment (2018 Measures No. 2) Bill 2019 which expands the regulation making powers to provide for exemptions on Australian Financial Services Licence and Credit Licence. The Bill was passed also has the effect of amending the Corporations Act $2001^{53}$ and National Consumer Credit Protection Act $2009^{54}$ to pave way for the players that are interested to carry out the limited financial activities and within the scope prescribed, to run for the sandbox testing.

\section{Financial Regulatory Architecture and Fintech Regulatory Sandbox in Malaysia}

The Malaysian financial regulatory architecture is dependent on the division of the work scope between financial institutions and financial markets. The financial system is diversified and relies on four main pillars which are banking, insurance, money markets and capital markets. ${ }^{55}$ The financial institutions are governed by BNM, ${ }^{56}$ while the money markets are governed by the Securities Commission ('SC'), ${ }^{57}$ except for offshore markets which fall under the supervision of Labuan Financial Services Authority. ${ }^{58}$ The main objective of $\mathrm{BNM}$ is to promote monetary and financial stability, ${ }^{59}$ whereas the

51 ASIC, CP 297 Retaining Asic's Fintech Licensing Exemption, 2017).

52 Ibid paragraph B 39.

53 Subsections (3), (4) and (5) were inserted in s 926B of the Corporations Act 2001 (Cth).

54 Subsections (2), (3) and (4) of National Consumer Credit Protection Act 2009 (Cth).

55 International Monetary Fund, Malaysia Financial Sector Assessment Program: Financial Sector Performance, Vulnerabilities and Derivatives, 2014) 6.

${ }^{56}$ Central Bank Malaysia Act 2009.

57 Securities Commission Act 1993.

58 Labuan Financial Services Authority Act 1996.

59 Bank Negara Malaysia, 'About the Bank ' 2019) <http://www.bnm.gov.my/index.php?ch=en_about\&pg=en_intro\&ac=64 1\&lang=en> accessed 17 May 2019. 
mission of SC is 'to promote and maintain fair, efficient, secure and transparent securities and derivatives markets; and facilitate the orderly development of an innovative and competitive capital market'. ${ }^{60}$

In Asia, one of the contributing factors for the emergence of fintech is mobile banking, especially mobile payments systems ${ }^{61}$ with Malaysia as one of the major player in the region. ${ }^{62}$ In 2016, Malaysia was identified as one of South East Asia's first countries to have achieved the highest level of financial inclusion based on the country's percentage of mobile banking utilization. ${ }^{63}$ Apart from that, e-money transactions were valued at RM1.92 billion in 2018 compared to RM1.82 billion in $2017 .^{64}$ All of these ascending growth trends in banking and payments systems indicate that fintech has played a big role in changing the Malaysian landscape in terms of credit creation and availability of financial services to the public at large.

Catalysed by the rapid changes in financial services, SC took the first step in forming the alliance of FinTech community known as 'aFINity' in $2015^{65}$ with two main objectives. Firstly, aFINity functions as the SC's platform to gather the fintech community so as to understand their regulatory concerns regarding their fintech businesses and render the appropriate guidance. Secondly, aFINity administers innovation labs in scrutinizing innovation ideas that are

${ }^{60}$ Securities Commission, 'About the SC' 2019) <https://www.sc.com.my/about/about-the-sc> accessed 17 May 2019

${ }^{61}$ Arner, Barberis, and Buckley, "The evolution of fintech: a new postcrisis paradigm.", 1280.

62 Bank Negara Malaysia, Financial Stability and Payment Systems Report 2016, 2016), 108.

${ }^{63}$ Jose De-Luna Martinez, Financial Inclusion In Malaysia : Distilling Lessons For Other Countries, 2017) Available at http://documents.worldbank.org/curated/en/703901495196244578/Finan cial-inclusion-in-Malaysia-distilling-lessons-for-other-countries.

${ }^{64}$ Bank Negara Malaysia, Financial Stability and Payments System Report 2018, 2018) 108.

${ }^{65}$ Capital Markets Malaysia, 'The Malaysian Capital Market: Connected, Vibrant, Innovative' (2016) 1 Nomura Journal of Asian Capital Markets 1415 . 
suitable with the Malaysian capital markets. ${ }^{66}$ Other responses by Malaysia in regulating fintech were the introduction of regulatory sandbox where, "financial institutions and fintech companies will be able to pilot innovations in a controlled, live-test environment with appropriate flexibilities accorded," $"$ "67 under the Financial Technology Regulatory Sandbox Framework ('Framework'). ${ }^{68}$ This is in line with BNM's mandate to which seeks financial inclusion participation for all members of the society in the financial system. ${ }^{69}$ Similar to ASIC's move, the first step taken by BNM before introducing the regulatory sandbox was to establish an innovation hub known as the Financial Technology Enabler Group ('the FTEG'). ${ }^{70}$

While some opine that SC's aFINity innovation lab is a type of sandbox, ${ }^{71}$ this paper argues otherwise. Although BNM's sandbox and SC's aFINity innovation labs share similar goals in regulating fintech, they are distinctive in terms of structure and operations. As stated earlier, the innovation lab was an expansion of aFINity to investigate the type of innovation that suits the fintech products in the capital market. ${ }^{72}$ The first innovation lab rendered under the aFINity umbrella was Project Castor. ${ }^{73}$ Under this Project, SC explored the operation of Distributed Ledger Technology ('DLT') or Block chain for unlisted and Over The Counter ('OTC') markets. By the end of

66 Chin Wei Min and Azrina Azmel, 'Developing a Facilitative Ecosystem for Digital Innovation in the Malaysian Capital Market' (2017) Nomura Journal of Asian Capital Markets 1415.

67 YBhg. Tan Sri Datuk Seri Utama Dr. Muhammad bin Ibrahim, Governor's Keynote Address at the 6th Malaysian Insurance Summit (Bank Negara Malaysia 2016).

68 Financial Technology Regulatory Sandbox Framework, 18 October 2016 http://www.bnm.gov.my/index.php?ch=57\&pg=137\&ac=533\&bb=file.

69 Bank Negara Malaysia, Financial Sector Blueprint 2011-2020, 2011).

70 Malaysia, Financial Stability and Payment Systems Report 2016, 108.

71 Nafis Alam, Lokesh Gupta, and Abdolhussein Zamani, Fintech and Islamic Finance: Digitalization, Development and Disruption (Switzerland: Palgrave Macmillan, 2019). 153.

72 Hazik Mohamed and Hassnian Ali, Blockchain, Fintech, and Islamic Finance: Building the Future in the New Islamic Digital Economy (Boston/Berlin: Walter de Gruyter Inc, 2019). 160.

73 Securities Commission, Project Castor: Capital Market Architecture Blueprint in a Decentralised World

(Securities Commission 2018). 
Project Castor, SC published a blueprint proposing the core principles in developing a decentralised market structure. ${ }^{74}$ Hence, it can be perceived that the blueprint only acts as a general guidance to fintech players specifically in relation to the usage of DLT in the unlisted and OTC markets.

Therefore, this paper further argues that the aFINity innovation lab does not share the same structure as regulatory sandbox in regulating fintech based on two main reasons. Firstly, there is no legal framework for the aFINity innovation lab. Secondly, aFINity has no dispute resolution framework for participants and investors. Furthermore, based on SC's response in an email interview dated 11 November 2019, it was observed that the SC's approach to fintech regulation is not through sandboxing but through 'providing legal certainty to the introduction of the various market structures through the SC's Guidelines on Recognized Markets'. ${ }^{75}$ This means that the aFINity lab serves as a consultation centre rather than a regulated and parameterized live environment unlike a sandbox. Therefore, the next discussion focuses on the Malaysian regulatory sandbox i.e., "Financial Technology Regulatory Sandbox Framework 2016 under purview of BNM.

\section{Malaysian regulatory sandbox and the Role of BNM}

BNM framework for fintech clearly carved out the players that would be eligible to participate in the regulatory sandbox. The eligibility only applies to financial institutions ${ }^{76}$ carrying out an authorised or registered financial business ${ }^{77}$ or holding appropriate money business licenses. ${ }^{78}$ Other players may also come from fintech companies with

${ }^{74}$ Ibid.

${ }^{75}$ Queries on aFINity lab.

${ }^{76}$ Referring to paragraph 4.1 of the framework, the definition of financial institutions includes all institutions listed under Financial Services Act 2013, Islamic Financial Services Act 2013, Money Services Business Act 2011 and Development Financial Institutions Act 2002.

77 The term authorised means both under Financial Services Act 2013 for conventional financial institutions and under Islamic Financial Services Act 2013 for Islamic financial institutions.

78 The activities are regulated under Money Services Business Act 2011. 
collaboration with financial institutions or fintech companies intending to carry out financial business or money business activities within the ambit permitted by the law. ${ }^{79}$

\section{Eligibility criteria}

BNM has listed several guidelines on the eligibility criteria that the players must meet before participation in the sandbox. In addition, BNM also takes several other criteria on the meaning on the meaning of the term 'innovation' in products and services. An innovative product or service must be able to improve productivity, quality and accessibility of the incumbent products and services. ${ }^{80}$ The product must also add value to the efficacy of how the Malaysian financial institutions manage risks. ${ }^{81}$ Ultimately, the product or service must be able to manage the gaps or open for new financing or investment openings in the Malaysian economy. ${ }^{82}$

79 The law here refers to Financial Services Act 2013, Islamic Financial Services Act 2013 and Money Services Business Act 2011.

80 "Financial Technology Regulatory Sandbox Framework," 2016, accessed $\quad 29 \quad$ August 2018, http://www.bnm.gov.my/index.php?ch=57\&pg=137\&ac=533\&bb=file (Guidelines), paragraph 5.1 (a) (i).

81 Ibid paragraph 5.1 (a) (ii).

82 Ibid paragraph 5.1 (a) (iii). 


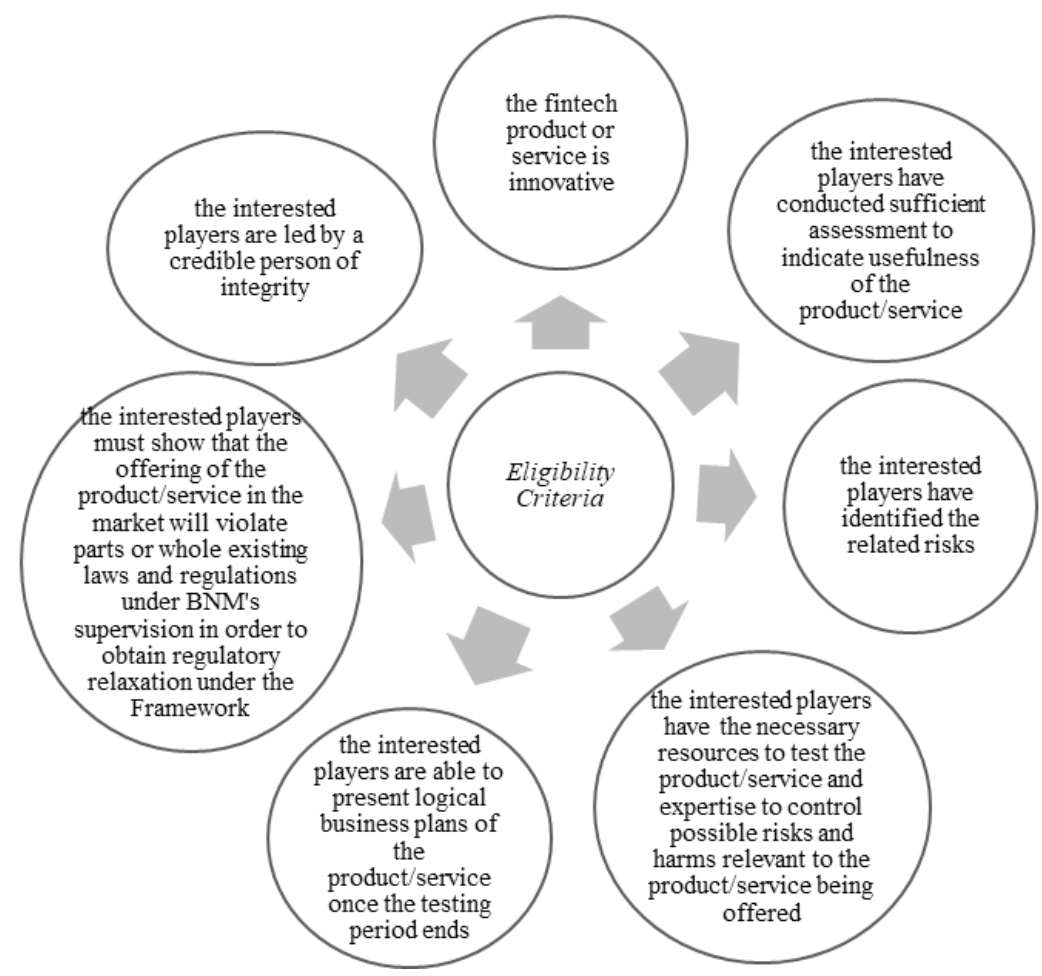

Figure 2: Eligibility criteria under Malaysian Regulatory Sandbox.

Source $^{83}$

Apart from the eligibility criteria listed in Figure 2 above, BNM also expressly states that fintech companies that collaborate with the financial institutions may have an added eligibility advantage in the Framework. ${ }^{84}$ As for fintech companies without existing collaboration with any financial institutions, BNM will give better consideration to them should they be able to prove that their innovative product or services to be or being offered will create job opportunities in Malaysia. ${ }^{85}$

83 Eligibility Criteria under BNM's Financial Technology Regulatory Sandbox Framework 2016.

84 Ibid paragraph 5.2.

85 Ibid paragraph 5.3 . 
Measures on identified possible risks relating to the fintech product or services

The framework requires interested players to present to BNM specific measures that they will undertake to mitigate or control the possible risks attached to the fintech product or services to be offered. BNM named a few measures which may be included during the application process under the Framework. However, the players may also come up with other measures that suit their fintech products or services.

In addressing the appropriate measures to contain the possible risks attached to the fintech product or service, it is pertinent for the intended players to provide adequate disclosure on the possible risks to their potential customers and confirmation from the customers that they have fully understood and accepted the same. ${ }^{86}$ The intended players may also limit the number of potential or existing participating customer or the total value of the transactions. ${ }^{87}$ Furthermore, the intended players may classify the customers according to their profiles ${ }^{88}$ in order to put a limit on possible concentration on one product. In addition, BNM also provided that a shorter testing period may also amount to measures to contain possible risks from materializing. ${ }^{89}$ It also BNM stated that the intended players shall provide consumer redress mechanisms that include clear positions on when and how the consumers may get compensated for their losses. ${ }^{90}$ Lastly, the intended players must be able to show that they bind themselves to appropriate resources and will implement risk mitigation that is proven effective should failure of the testing materialize.

\section{Expiry and termination of the testing period}

The testing period for each fintech player shall be 12 months except if the player is granted an extension..$^{91}$ Under the regulation, should the

86 Ibid paragraph 6.3 (a).

87 Ibid paragraph 6.3 (b).

88 Ibid paragraph 6.3 (c).

89 Ibid paragraph $6.3(\mathrm{~d})$.

90 Ibid paragraph 6.3 (e).

91 To apply for the extension, the player shall notify BNM 30 days before the expiry of the initial testing period. 
player require an extension, it shall specify the amount of time required with reasons. ${ }^{92}$ If the player succeeds in testing within the expiry date, it shall then apply for the appropriate licensing or registration under the required law. ${ }^{93}$

However, if the player fails, the products and/or services will be prohibited from entering the Malaysian market. Failure of the testing may occur pursuant to the expiry of the testing period ${ }^{94}$ or during the testing period. ${ }^{95}$ When failure of testing happens, the players are obligated to perform their exit plan as soon as they are aware of the failure. The players shall also notify all consumers of the failure and provide a guide for the rights for redress, if applicable. In addition, the players shall compensate the consumers in accordance with the measures submitted to BNM in the regulatory sandbox application. Lastly, the player is under the obligation to submit a report within 30 days after revocation. ${ }^{96}$

From the key features stated above, it can be concluded that BNM takes on a fully flexible approach in regulating fintech businesses. From the framework, it has been observed that there are no hard and fast rules for determining the number of consumers for each fintech player. Similarly, the testing period is fixed at 12 months period with the possibility of extension of time depending on the reasons and situation of the fintech players. These reliefs are on a case-by-case basis and subject to the discretion of BNM.

In June 2019, it was announced during Malaysia's first inaugural fintech event, myfintechweek that MoneyMatch Sdn Bhd was the first player that had officially graduated from the Malaysian Regulatory Sandbox. ${ }^{97}$ MoneyMatch is an international fintech company carrying

92 Ibid paragraph 9.2.

93 Ibid paragraph 9.3 .

94 Ibid paragraph 9.4

95 Ibid paragraph 10.1; BNM has listed a number of instances whereby mostly are when the players contravene the rules and laws applicable to them.

96 Ibid paragraph 10.4 .

97 Fintech News Malaysia, 'MoneyMatch Announced as First to Graduate BNM's Sandbox at MyFintechWeek' (Fintech News Malaysia, 2019) $<$ https://fintechnews.my/20883/payments-remittance- 
out remittance and cross border payment services ${ }^{98}$ that was approved to participate in the Malaysian Regulatory Sandbox in July 2017. MoneyMatch was also one of the first fintech players that was approved to conduct the enabling technology of 'electronic know your customer' ('e-KYC') via its mobile app in carrying out the business. This marks the first Malaysian fintech player's successful exit from the Regulatory Sandbox.

\section{COMPARATIVE ANALYSIS OF FINTECH REGULATORY SANDBOXES IN AUSTRALIA AND MALAYSIA}

In Australia and Malaysia, different forms of sandboxes have been identified as one of the ways to provide regulatory oversight and ensure that appropriate regulation captures disruptive financial products and services. This provides comparative analysis i.e., common feature and differences of sandboxes in both jurisdictions.

\section{Common Features Found in a Structure of a Regulatory Sandbox}

From the foregoing discussion of both Australian and Malaysian sandboxes, it can be recapitulated that the structure of a basic regulatory sandbox consists of: regulatory objectives that are parallel with other regulatory functions; provision of eligibility criteria in for players, participants and innovative product; time limit for testing innovative products; effective consumer protection framework; proper dispute resolution mechanism; and exit strategies during and after the testing stage.

malaysia/moneymwatch-graduate-bank-negara-malaysia-sandbox/> accessed 18 June 2019.

${ }^{98}$ MoneyMatch, 'About Us' 2019) <https://transfer.moneymatch.co/aboutus> accessed 24 June 2019. 
The common features in the selected jurisdictions is highlighted in Table 2 below:

\begin{tabular}{|c|c|c|}
\hline Jurisdiction & \multirow[t]{2}{*}{ Australia } & \multirow[t]{2}{*}{ Malaysia } \\
\hline Components & & \\
\hline Regulatory Agency & $\begin{array}{l}\text { Australian Securities } \\
\text { and Investment } \\
\text { Commission }\end{array}$ & Bank Negara Malaysia \\
\hline $\begin{array}{l}\text { Regulatory powers } \\
\text { conferred under: }\end{array}$ & $\begin{array}{l}\text { Corporations } \quad \text { Act } \\
2001(\text { Cth })\end{array}$ & Central Bank Act 2009 \\
\hline $\begin{array}{l}\text { Regulatory } \\
\text { Objectives: }\end{array}$ & $\begin{array}{l}\text { Innovation } \\
\text { transform } \\
\text { Government. }\end{array}$ & Financial inclusion \\
\hline $\begin{array}{l}\text { Eligibility criteria to } \\
\text { enter sandbox: }\end{array}$ & $\begin{array}{l}\text { (i) Must be new } \\
\text { (ii) Will provide } \\
\text { consumer benefit }\end{array}$ & $\begin{array}{l}\text { (i) Will serve the } \\
\text { domestic market; } \\
\text { (ii) Create job } \\
\text { opportunities; } \\
\text { (iii) Players shall } \\
\text { tabulate the risk } \\
\text { assessments and } \\
\text { measures that they will } \\
\text { take to counter those } \\
\text { risks. }\end{array}$ \\
\hline $\begin{array}{lr}\text { Measures } & \text { and } \\
\text { standards } & \text { of } \\
\text { sandbox testing: } & \end{array}$ & Conditions of relief & $\begin{array}{l}\text { Listed measures stated } \\
\text { in the Framework. }\end{array}$ \\
\hline
\end{tabular}




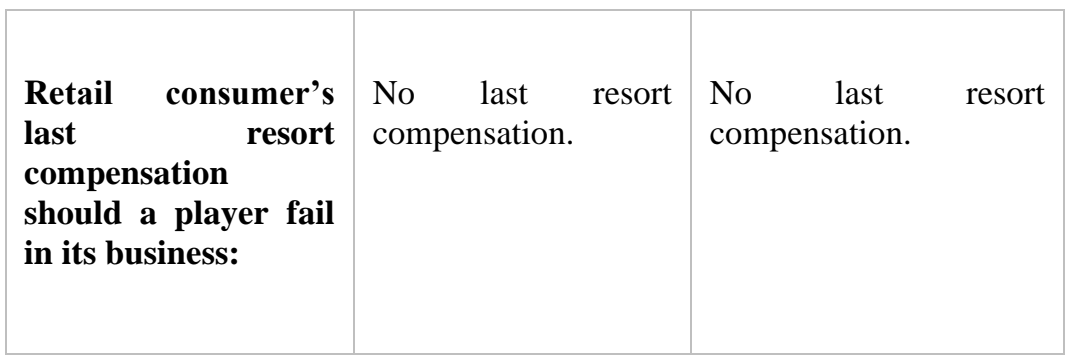

Table 2: Comparison of Sandboxes Regulation in Australia and Malaysia

\section{Objectives of a Regulatory Sandbox}

The jurisdictions that take up regulatory sandbox and place it into their financial system usually pursue the objectives of ensuring financial stability, consumer and investor protection, financial inclusion and promoting innovation or competition. ${ }^{99}$ The regulatory sandbox objectives vary from one financial system to the other. ${ }^{100}$ In Australia, there is a focus on increasing economic growth and prosperity by focusing on innovation, science and research. Interestingly, the Malaysian regulatory sandbox rests its' policy objective on financial inclusion. This might be because of its suitability with the Malaysian economy that is still in the pendulum swing of a developing nation. Although financial inclusion through regulatory sandbox is supported by international bodies and organizations, ${ }^{101}$ the latest report from the United Nations SecretaryGeneral's Special. Advocate for Inclusive Finance for Development (UNSGSA) stated that regulatory sandbox is not

99 Board, Financial Stability Implications from FinTech: Supervisory and Regulatory Issues that Merit Authorities'Attention. 4-5.

${ }^{100}$ Hilary J Allen, 'Sandbox Boundaries' Washington College of Law Research Paper accessed 7 November 2019.

${ }^{101}$ See Ivo Jenik and Kate Lauer, 'Regulatory Sandboxes and Financial Inclusion' (CGAP, 2017)accessed October 2017 UNSGSA Fintech SubGroup on Regulatory Sandboxes, Briefing on Regulatory Sandboxes (United Nations Secretary-General's Special Advocate for Inclusive Finance for Development 2017). 
necessarily the right answer to financial inclusion. ${ }^{102}$ Nevertheless, based on a survey ran by the independent body Consultative Group to Assist the Poor ('CGAP') together with the World Bank in May 2019, CGAP is of the opinion that the regulatory sandbox can further the objective of financial inclusion with a new approach of thematic sandboxes. ${ }^{103}$ Thematic sandboxes refer to the specific policy goals that the regulators want to achieve and place of the regulated entity on a specified track to pursue such policy goals. It was reported that BNM is currently active in developing thematic sandboxes. ${ }^{104}$

\section{Innovation $\mathrm{Hub}$}

Based on the observation of both jurisdictions, the main similarity between ASIC and BNM is the establishment of Innovation Hubs. Innovation hubs acts as platforms for regulators, players and other stakeholders to communicate openly and provides dialogical approach in regulation. Both regulators utilized their innovation offices as a regulatory toolkit to balance between sound regulation, innovation and consumer protection.

The clear contention of having an open communicative relationship between the regulators, players and other stakeholders is to for continuous learning and responsive regulation. ${ }^{105}$ This is why innovation hubs are typically the first step taken by regulators before embarking on other means of fintech regulation. Besides serving as a place for the stakeholders to exchange and learn new innovative

${ }^{102}$ UNSGSA FinTech Working Group and CCAF, Early Lessons on Regulatory Innovations to Enable Inclusive Fintech: Innovation Offices, Regulatory Sandboxes and Regtech., 2019).

103 "Do Regulatory Sandboxes Impact Financial Inclusion? A Look at the Data," Regulatory Sandboxes: What Have We Learned So Far?, CGAP, 2019, accessed 1 October 2019, https://www.cgap.org/blog/doregulatory-sandboxes-impact-financial-inclusion-look-data.

${ }^{104}$ Malaysia, Financial Stability and Payments System Report 2018.

${ }^{105} \mathrm{CCAF}$, Early Lessons on Regulatory Innovations to Enable Inclusive Fintech: Innovation Offices, Regulatory Sandboxes and Regtech. 4. 
ideas, the innovation hub also serves as a coordinator between the regulators and players. ${ }^{106}$

\section{Regulatory agencies governing the sandbox}

The scope of the respective regulator that handles regulatory sandbox has been explained thoroughly above. When it comes to fintech regulation, in Australia ASIC is the single market conduct regulator within its jurisdiction to regulate and supervise such subject matters. This is different from Malaysia's standpoint where certain subject matters on financial markets will be under SC's supervision in consonance with BNM, unlike ASIC, which holds the sole regulatory sandbox without other regulators acquiring regulatory powers over fintech products and/or services.

\section{Eligibility criteria}

The eligibility criteria set out in the two different frameworks can also be included as similar features of a regulatory sandbox structure. Both jurisdictions have stated that the main criterion is for the players to show that the products and services are innovative and will bring consumer benefit. However, the approach of the regulators in evaluating whether or not the players are eligible differs. BNM focuses more on how the products and services will serve the domestic market and financial inclusion. ASIC on the other hand only requires the players to write a short description of its innovative products and/or services and explain further on how the products and/or services shall be provided to the consumers.

Thus, the issue in question is the definition of the term innovation. BNM has provided an extensive definition of the term innovation. Meanwhile, the enhanced regulatory sandbox in Australia acknowledges that innovation may include new products that are yet to enter the market or any improvements that one can make to the existing products. ${ }^{107}$ Understandably, it is difficult to have an

${ }^{106}$ Buckley et al., "Building Fintech Ecosystems: Regulatory Sandboxes, Innovation Hubs And Beyond." 5.

${ }^{107}$ s 16 Government of Australia, Corporations (FinTech Sandbox Australian Financial Services Licence Exemption) Regulations 2020 
exhaustive list of what amounts to innovation as technology and demands of financial products changes from time to time. In short, BNM holds the upper hand in controlling the types of players that would be allowed to participate in the sandbox. BNM also have the authority to tailor- the measures that are applicable to the players participating in the sandbox in accordance with their business models. On the other hand, the scope of measures toward Australian fintech in its sandbox applies the regulatory requirements issued by ASIC thoroughly without any changes. ${ }^{108}$

\section{Standards of the sandbox testing and consumer protection.}

Several thresholds have been clearly illustrated in ASIC's conditions for relief and BNM's Framework in determining the types of standards expected from the players with regards to testing and consumer protection.

Regulation on testing and duration of fintech are quite similar and flexible in both jurisdictions. In Malaysia, the duration is fixed to 12 months, although both jurisdictions provide flexibility for players to apply for extension of time. In Australia, the time limit is up to 24 months with a review by the minister on the 12 th month of testing. ${ }^{109}$ Time limits should differ based on the business models and the opportunity of exploration of other regulatory instruments to support the fintech regulatory environment. An example of this is the development of e-KYC in Malaysia. ${ }^{110}$ From the data collected during

(2020) and s 13 Government of Australia, National Consumer Credit Protection (FinTech Sandbox Australian Credit Licence Exemption) Regulations 2020 (2020).

${ }^{108}$ Bromberg, Godwin, and Ramsay, "Fintech Sandboxes: Achieving Balance Between Regulation And Innovation.".

${ }^{109}$ s 7Australia, Corporations (FinTech Sandbox Australian Financial Services Licence Exemption) Regulations 2020 and s 7 Australia, National Consumer Credit Protection (FinTech Sandbox Australian Credit Licence Exemption) Regulations 2020.

${ }^{110}$ Bank Negara Malaysia, 'Anti-Money Laundering and Counter Financing of Terrorism (AML/CFT) - Money Services Business (Sector 3) (Supplementary Document No. 1)' (Bank Negara Malaysia, 2017) <http://www.bnm.gov.my/index.php?ch=57\&pg=146\&ac=650\&bb=file $>$ accessed 17 May 2019. 
the testing stage in the Malaysian regulatory sandbox, there was a need for a faster solution in authenticating customers utilizing online and mobile remittance services. ${ }^{111}$ Therefore, in order to lay out the appropriate regulations that match with digitalized remittance service providers such as MoneyMatch, more time was given to these players in order for e-KYC to be developed in Malaysia. From the Malaysian example, it is important for players to adhere to the fixed time frame in order to commit them to the required periodic reporting to the regulators. Nevertheless, this measure can also be made flexible based on the scope of the transaction as applicable under the Australian regulatory sandbox. Similarly, it could be based on specific risks and opportunities arising from the business model itself as applicable under BNM e-KYC framework. This flexibility will assist the regulators to learn new risks and match the best way to regulate the risks attached with the innovative business.

The type of products and services offered and the targeted consumers and redress mechanism in another feature in the sandbox. The paramount consideration that regulators are focused on is the protection of the consumers. Therefore, the players are under the obligation to have full disclosure of the types of products and services to the consumers. It is important for the consumers to be aware of the risks associated with such products and services. The best practice of a consumer protection framework in financial services is the existence of last resort redress and compensation mechanism if the business fails. ${ }^{112}$ Even so, the customers in sandboxes will have to deal with the possibility of insufficient protection during the testing period. ${ }^{113}$ Eventually, the parameters defined by the regulators and the regulatory relaxation that they may provide to the players in the sandbox will be the determining factor of the extent of protection that the customers can fall back on. ${ }^{114}$ Both Australia and Malaysia's sandboxes have emphasised the importance of consumer protection and safeguard without specifying appeal process and last resort schemes.

111 Ibid.

${ }^{112}$ Bromberg, Godwin, and Ramsay, "Fintech Sandboxes: Achieving Balance Between Regulation And Innovation.", 325.

${ }^{113}$ Ibid.

${ }^{114}$ Ibid. 
In Malaysia, the Financial Services Act 2013 under the purview of BNM does not provide an exact definition to distinguish between retail and sophisticated customers. However, in order for the interested players to enter the sandbox, BNM must be satisfied that the players have the necessary resources and expertise to support the testing stage in reducing and/or controlling possible losses and risks that may arise from the players' services, businesses or financial products. ${ }^{115}$ Additionally, the players are required to prove that they will provide a consumer redress mechanism which includes a financial compensation claimable by the customers under clearly specified circumstances, including in instances where their business might fail. ${ }^{116}$ Furthermore, the players have to prove that they are committed to providing a venue with ample resources during the testing stage. They also need to show that the solutions they opt for in reducing risks have been proven to be effective should their business fail. ${ }^{117}$

The requirements demanded by BNM as seen above reflect that last resort compensation schemes are not available for the retail customers. The same also applies to the Australian setting. ${ }^{118}$ This has been highlighted by CHOICE, the leading Australian consumer advocacy group that ASIC consulted for the implementation of regulatory sandbox. ${ }^{119}$ CHOICE's submission to ASIC expressly stated that it opposed the sandbox framework as there is no last resort compensation scheme for consumers especially for those who are more vulnerable.

${ }^{115}$ Bank Negara Malaysia, 'Financial Technology Regulatory Sandbox Framework' 2016) <http://www.bnm.gov.my/index.php?ch=57\&pg=137\&ac=533\&bb=file $>$ accessed 29 August 2018, paragraph 6.

116 Ibid.

${ }^{117}$ Ibid.

${ }^{118}$ Further information about adequate compensation arrangements maintained by licensees can be found in Australian Regulatory Guide 126 Compensation and insurance arrangements for AFS licensees (RG 126) and Regulatory Guide 210 Compensation and insurance arrangements for credit licensees (RG 210).

${ }^{119}$ Australia CHOICE, 'About us' (CHOICE, 2019) <https://www.choice.com.au/about-us> accessed 19 May 2019. 
Synthesizing from the Australian and Malaysian sandbox structure, it is important to note that there are two reasons on the nonexistence of a last resort compensation scheme. Firstly, both regulators have the powers to revoke the players' participation in sandbox at any time. For BNM, it holds the absolute discretion to revoke its approval to any of the fintech players. This shall be in instances when BNM becomes aware that any player has failed to effectively address any defects that arise from the products and/or services that the player offered. ${ }^{120}$ The same applies to ASIC, where in anytime that ASIC is aware that any of the players do not comply with the prescribed condition; ASIC has the power to stop the player from participating in the sandbox. ${ }^{121}$

Furthermore, both jurisdictions do not have last resort compensation scheme due to how narrow their sandboxes are. The listed financial services and activities under the purview of both Malaysian and Australian sandboxes' framework are very limited. Most of the financial services and activities allowed are a type of a financial service provider or a financial intermediary instead of dealing with public money for deposit taking or investment purposes. Thus, both ASIC and BNM opine that there is no necessity to have the last resort compensation scheme.

Even so, there are still problems in Australia for the nonexistence of last resort compensation. CHOICE - consumer advocacy group in Australia highlighted that the current compensation scheme by Financial Ombudsman or through External Dispute Resolution had not been positively implemented. There are still payments that have

${ }^{120}$ Malaysia, 'Financial Technology Regulatory Sandbox Framework'accessed, paragraph 10-11.

${ }^{121}$ Richard St. John, Compensation Arrangements for Consumers of Financial Services-Report, (Australia: Treasury, 2012). Australia, Division 1 Part 3 of the Australia, Corporations (FinTech Sandbox Australian Financial Services Licence Exemption) Regulations 2020 and Australia, National Consumer Credit Protection (FinTech Sandbox Australian Credit Licence Exemption) Regulations 2020 ; s $926 \mathrm{~B}$ of the Corporations Act 2001 (Cth). 
not been made to the consumers due to the failure of the financial products and services offered. ${ }^{122}$

Another point on the threshold of regulatory sandbox is that, it must be structured with an exit strategy prepared by the players during the application stage. This also goes back to the principle of consumer protection. The players are expected to draw up the possibilities of the risks attached to the products.

\section{DIFFERENCES BETWEEN MALAYSIAN AND AUSTRALIAN SANDBOXES}

The main difference between the Malaysian regulatory sandbox and the Australian sandbox is on the issue of regulatory transparency. In addition, other major differences are illustrated based on the status of players participating in the sandbox. Previously, the list of approved fintech players in the Malaysian sandbox could be accessed through the FTEG website. ${ }^{123}$ However, the website is no longer active and this could amount to lack of transparency in the Malaysian sandbox regulation. It also shows downsides of having a sandbox. ${ }^{124}$ Due to lack of transparency, concerns on systemic risks will heighten as equal opportunity for regulatory reliefs are not applicable to other financial service providers who are not fintech players in a normal regulatory environment. Furthermore, consumer concerns will also increase due to the non-disclosure. ${ }^{125}$ Thus, a communicative approach in regulating financial technology requires sandbox transparency in order to achieve legal certainty.

${ }^{122}$ Australia CHOICE, 'Consultation paper 260: Further measures to facilitate innovation in financial services. Submission to the Australian Securities and Investments Commission' (ASIC, 2016) <http://download.asic.gov.au/media/4111502/choice.pdf> accessed 19 May 2019.

${ }^{123}$ Financial Technology Enabler Group, 'List Of Approved Participants In Regulatory Sandbox' 2017) <https://www.myfteg.com/approvedparticipants-in-sandbox> accessed 1 September 2018.

${ }^{124}$ See Zetzsche et al., "From regulatory sandboxes to smart regulation." 80 and Awrey, "Regulating Financial Innovation: A More Principles-Based Alternative."

${ }^{125}$ Zetzsche and others, 'From regulatory sandboxes to smart regulation' 80. 
On the other hand, this situation however does not exist under ASIC. As one of the Australian Government agencies, ASIC upheld the Australian Freedom of Information Act 1982 (Cth), which guarantees the right of access to documents held by the Government or any of its agencies. Therefore, all types of documents relating to regulatory sandbox will be published in ASIC's website or may be requested through the Act through the Office of the Australian Information Commissioner. ${ }^{126}$ The status of the players (both completed and currently active) in its regulatory sandbox is clearly stated in the ASIC's website. Nevertheless, we recognise that it is the prerogative of the Malaysian regulator i.e. BNM whether to disclose any information on the regulatory sandbox to the public since there is no equivalent laws in Malaysia except in the State of Selangor ${ }^{127}$ and Penang. ${ }^{128}$ Both Penang and Selangor state freedom of information laws are only applicable for disclosure on the state's government document and financial regulation is exclusive National laws.. Since there is no law in compelling for transparency and disclosure, BNM is under no obligation to disclose and may view that the information on the players are confidential. As one of the thrusts in principles-based regulation rests on transparency, ${ }^{129} \mathrm{BNM}$ needs to re-align its policies on its sandbox to have better disclosure policies.

From the analyses of both jurisdictions in implementing regulatory sandboxes, it would be useful to also note the main benefits derived from both regulatory approaches. In Australia, the fintech players would greatly benefit from the newly enhanced regulatory sandbox as the new laws have widened the types of products and lengthen the period of sandbox testing. Conversely, the Malaysian sandbox approach is only focused on the products and services regulated by BNM. Thus, the fintech players would be able

${ }^{126}$ Office of the Australian Information Commissioner, 'Freedom of Information Act $1982 \quad$ (Cth)' (OAIC, 2019) <https://www.oaic.gov.au/freedom-of-information/foi-act> accessed 19 May 2019.

${ }^{127}$ Freedom of Information (State of Selangor) Enactment 2011, accessed 4 March 2020, https://www.selangor.gov.my/index.php/pages/view/97.

${ }^{128}$ Penang Freedom of Information Enactment 2010, accessed 20 April 2020, https://www.penang.gov.my/images/pdf/Warta\%20Enakmen.pdf.

${ }^{129}$ Awrey, "Regulating Financial Innovation: A More Principles-Based Alternative." 
to focus their fintech business model. Nevertheless, despite the benefits, the main downside of both sandboxes is their structure. Both approaches are narrow in defining their sandboxes ${ }^{130}$ which might defeat the purpose of having a sandbox in the first place. ${ }^{131}$ The fintech players would still find it a hurdle to enter the market. Be that as it may, ASIC and BNM have tried to shoulder the new regulatory burden through this new toolkit. Looking at both jurisdictions, the flow of regulatory sandbox in general can be encapsulated as follows:

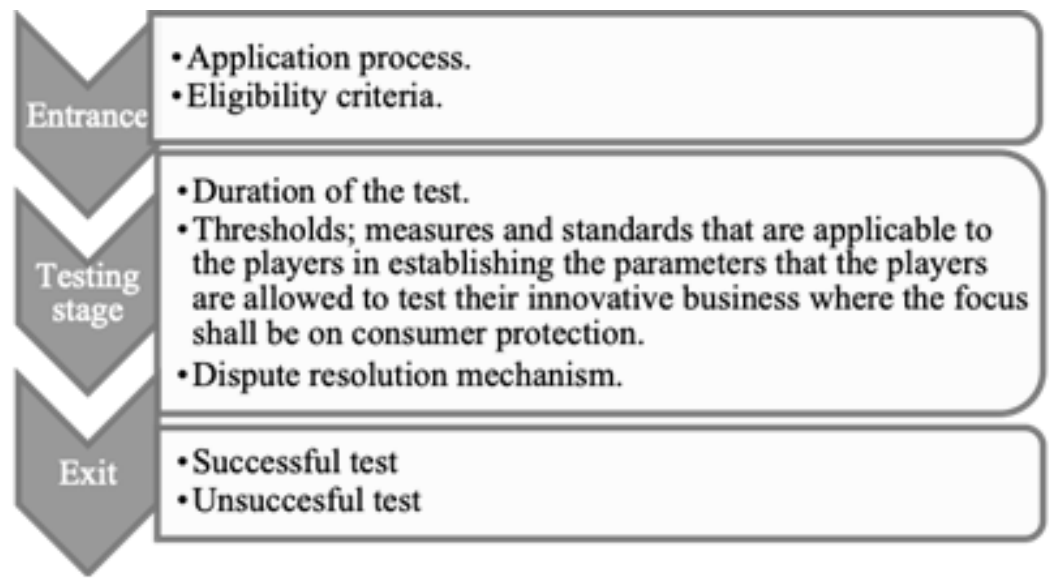

Figure 3: Flow chart of regulatory sandbox. ${ }^{132}$

Both regulators in Australia and Malaysia have, to a certain extent, provided an adequate framework in regulating fintech while balancing their other regulatory burdens to protect financial consumers and ensure financial stability without stifling innovations.

${ }^{130}$ Buckley and others, 'Building Fintech Ecosystems: Regulatory Sandboxes, Innovation Hubs And Beyond'; Both regulators have narrowly defined their sandboxes as a parameterized live environment with lax regulations where only fintech players that possess certain requirements and certain business models may interact with financial consumers under the supervision of the financial regulators to test out financial products and/or services that leverage on technology.

${ }^{131}$ Financial Conduct Authority, 'Regulatory Sandbox'accessed ; Regulatory Sandbox was introduced to reduce barriers in entering the market.

${ }^{132}$ Source Author. 


\section{CONCLUSION}

The concept of sandbox has its origins outside Malaysia and Australia but has been adopted beyond the United States and United Kingdom. From the foregoing discussions, it can be concluded that there are no international standards or best practices to follow in working out a regulatory structure within a jurisdiction for fintech. However, it is prudent to look at different designs of regulatory sandboxes that serves the demands of the market, ensure financial stability and consumer protection. Comparatively, the structures of the regulatory sandboxes in Australia and Malaysia have common peculiarities and flexibilities despite their marked differences. Nonetheless, distinct approaches are applied in each country. The reason behind the different approaches lies in the complex web of the financial system that is unique to the jurisdiction itself.

Most importantly, regulators must be aware that regulatory sandbox should not be regarded as keeping up with the Joneses. The Australian and Malaysian regulatory sandboxes have shown that the structure of a regulatory sandbox must respond to the need and local exigencies of the financial system in the respective jurisdiction. 